\title{
Pengembangan Kinerja Organisasi: Menggali Minat Untuk Menjadi Anggota Koperasi Mahasiswa Di Universitas Udayana Bali
}

\author{
I Gusti Agung Ketut Gede Suasana ${ }^{\left.1^{*}\right)}$ \\ Fakultas Ekonomi dan Bisnis Universitas Udayana \\ Anak Agung Gede Suarjaya ${ }^{2)}$ \\ Fakultas Ekonomi dan Bisnis Universitas Udayana \\ I Made Dana ${ }^{3)}$ \\ Fakultas Ekonomi dan Bisnis Universitas Udayana \\ *)Email: agung_suasana@unud.ac.id
}

\begin{abstract}
Abstrak
Koperasi mahasiswa (Kopma) adalah jenis koperasi di Indonesia yang beranggotakan mahasiswa. Data empiris menunjukkan bahwa partisipasi mahasiswa untuk menjadi anggota Kopma masih tergolong sangat rendah. Penelitian ini bertujuan menjelaskan; pengaruh manfaat ekonomi terhadap minat berkoperasi mahasiswa, pengaruh manfaat non-ekonomi terhadap minat berkoperasi mahasiswa, pengaruh persepsi terhadap minat berkoperasi mahasiswa, peran persepsi memediasi pengaruh manfaat ekonomi, dan manfaat nonekonomi terhadap minat berkoperasi mahasiswa. Penelitian dilakukan terhadap mahasiswa Fakultas Ekonomi dan Bisnis Universitas Udayana, dengan ukuran sampel 175 orang, dianalisis dengan Analisis Jalur (Part Analysis). Penelitian menemukan bahwa manfaat ekonomi signifikan menentukan persepsi dan minat berkoperasi. Manfaat non-ekonomi signifikan terhadap persepsi dan minat berkoperasi. Hasil lain ditemukan bahwa persepsi juga menentukan minat berkoperasi., dan persepsi berperan signifikan mediasi secara parsial pengaruh manfaat ekonomi, dan non-ekonomi terhadap minat berkoperasi. Hasil tersebut mengindikasikan bahwa ekspektasi mahasiswa terhadap manfaat ekonomi, dan non ekonomi pada Kopma cukup besar. Variabel-variabel tersebut dapat dihandalkan untuk membangun persepsi positif dan menarik minat mahasiswa menjadi anggota Kopma. Implikasinya adalah, Kopma harus bisa mengembangkan inovasi yang dapat dipersepsikan positif sesuai dengan ekspektasi mahasiswa. Hal tersebut dapat mendorong kinerja Kopma melalui peningkatan jumlah partisipasi untuk menjadi anggota.
\end{abstract}

Kata Kunci: manfaat ekonomi, manfaat non-ekonomi, persepsi pada koperasi, minat berkoperasi.

\section{Pendahuluan}

Koperasi yang kuat dan kompetitif adalah tanggung jawab bersama anggota, pengurus, manajemen, dan karyawan, di mana sasaran koperasi yang beragam dan pengelolaan yang demokratis membuat koperasi menjadi bisnis yang unik dan menantang (Zeuli and Cropp, 2004). Koperasi adalah salah satu pilar pembangunan, dan telah dikenal sebagai soko guru perekonomian Indonesia. Pernyataan tersebut diperkuat dengan ketentuan dalam pasal 33 (ayat 1) Undang-Undang Dasar Republik Indonesia 1945 dan Undang-Undang No. 25 Tahun 1992 tentang Perkoperasian. Koperasi yang berkinerja harus progresif, beradaptasi dengan perubahan iklim bisnis, serta responsif terhadap perubahan kebutuhan dan kemakmuran anggotanya. Kinerja tersebut menuntut setiap anggota, pengurus, dan pengelola konsisten pada tanggung jawab masing-masing terhadap koperasi. Kemakmuran anggota akan tercapai apabila koperasi diatur, dibiayai, dan dikelola dengan baik, didukung oleh anggota yang berkomitmen. 


\section{Gusti Agung Ketut Gede Suasana ${ }^{1}$, Anak Agung Gede Suarjaya ${ }^{2}$, I Made Dana ${ }^{3}$}

Koperasi yang kuat selayaknya mengharuskan ketiga kelompok tersebut untuk melakukan tugas dan tanggungjawabmya masing-masing.

Tingkat pertumbuhan dan partisipasi anggota adalah salah satu ukuran kinerja koperasi, namun perkembangan kinerja organisasi koperasi di Indonesia, nampaknya tidak secerah organisasi sektor usaha lain. Jumlah anggota yang selalu meningkat setiap tahun, merupakan salah satu indikator kinerja koperasi berkualitas (Puspayoga, 2017 dalam indotimes.co.id, 2017). Hal tersebut dicanangkan dalam program reformasi total koperasi di seluruh Indonesia, yang mencakup; rehabilitasi, reorientasi, dan pengembangan koperasi. Namun, harus diakui bahwa nama, makna, dan peran koperasi dalam kancah perekonomian nasional belum terlalu popular, khususnya di kalangan kaum milenial. Generasi milenial usia 17-30 tahun yang jumlahnya mencapai 60 persen dari total penduduk Indonesia, tidak paham dan tidak tertarik pada koperasi (Koperasi \& UKM, 2017). Artinya, minat masyarakat khususnya mahasiswa untuk menjadi anggota koperasi masih sangat rendah. Di sisi lain, pembelajaran tentang koperasi sudah dimulai sejak pendidikan usia dini hingga di perguruan tinggi. Di antara masalah utama yang dihadapi koperasi adalah kurangnya komitmen pengurus, kegagalannya dalam menjalankan tugas secara efektif dan lemahnya kepemimpinan yang mempengaruhi efektivitas dan kinerja pengurus (Hashim et al., 2018). Faktanya, persepsi masyarakat terhadap kinerja koperasi di dalam memberikan manfaat yang diharapkan oleh anggotanya dianggap belum memadai.

Minat adalah keinginan kuat seseorang untuk mencapai apa yang diinginkan dan tidak akan membiarkan hal apapun yang dapat menggangu pencapaian tersebut (Dyer, 2010). Minat merupakan kecenderungan dan kegairahan yang tinggi atau keinginan yang besar terhadap sesuatu (Muhibbin, 2011). Minat dapat direpresentasikan sebagai efek linier dan merujuk kepada faktor daya tarik yang mempengaruhi perilaku tertentu. Semakin kuat minat seseorang, maka semakin besar kemungkinan perilaku tersebut dilakukan, atau dapat dikatakan bahwa minat adalah kecenderungan spesifik individu untuk suatu tindakan atau serangkaian tindakan. Jadi penentu utama minat adalah keyakinan seseorang untuk memulai dan menjalankan sesuatu. Oleh karena itu, minat dapat dijadikan sebagai pendekatan dasar yang masuk akal untuk memahami apasaja yang menentukan daya tarik seseorang menjadi anggota koperasi.

Penelitian tentang minat berkoperasi sebagian besar ditentukan oleh persepsi dan manfaat yang dibutuhkan secara individu atas kinerja yang ditawarkan koperasi. Persepsi terhadap pengetahuan, manfaat, dan pemahaman terhadap koperasi memberikan efek positif terhadap minat mahasiswa menjadi anggota koperasi (Kusumantoro, 2010). Persepsi anggota tentang partisipasinya di dalam fungsi kontrol justru melebihi faktor lain dalam menjelaskan keterlibatan dan kepercayaannya pada pengurus koperasi (Osterberg and Nilsson, 2009). Jenisjenis koperasi di Indonesia cukup banyak dan jika dilihat dari keanggotaan, maka salah satu di antaranya adalah koperasi mahasiswa (Kopma). Kopma adalah jenis koperasi yang beranggotakan mahasiswa dan skaligus dapat dijadikan sebagai wadah kegiatan kewirausahaan bagi mahasiswa. Peran Kopma, adalah sebagai; ajang pembelajaran pengelolaan koperasi dan mengembangkan potensi kewirausahaan, serta sarana membangun sikap mental kepemimpinan, berorientasi tugas dan hasil, orientasi masa depan, kreativitas, pengambilan risiko dan percaya diri (Thoharudin dan Suriyanti, 2017). Hasil penelitian ditemukan bahwa; rapat anggota kurang maksimal, pelaksanaan kewajiban pengurus Kopma belum maksimal, pengelolaan sumberdaya tidak optimal (Amriadi, dkk., 2017). Oleh sebab itu, Kopma seharusnya lebih sering mengadakan kegiatan yang mendukung aktivitas akademis ataupun non akademis, lebih memperhatikan kebutuhan anggota, dan memberi kesempatan kepada anggotanya untuk mendalami kemampuan kepemimpinannya (Putra dkk., 2014).

Persepsi adalah suatu proses penginderaan (proses sensori) yaitu proses diterimanya stimulus oleh individu melalui alat indera (Walgito, 2010). Proses tersebut tidak akan berhenti 


\section{Gusti Agung Ketut Gede Suasana ${ }^{1}$, Anak Agung Gede Suarjaya ${ }^{2}$, I Made Dana ${ }^{3}$}

begitu saja melainkan sebagai stimulus yang berkelanjutan, karena proses persepsi tidak dapat lepas dari proses penginderaan sebagai pendahulu proses persepsi (Alliah dkk., 2016). Pengertian tersebut bermakna bahwa persepsi mahasiswa dapat ditentukan atas penginderaan terhadap kinerja Kopma yang memberikan manfaat kepada anggotanya. Kinerja koperasi seperti halnya usaha lain, dapat diukur secara finansial dan non-finansial. Secara finansial, dapat tercermin pada bagian sisa hasil usaha, sedangkan non-finansial dapat berupa kepuasan atas kinerja pelayanan yang diterima dari koperasi.

Literatur dan bukti empiris telah menunjukkan bahwa kualitas pelayanan berpengaruh signifikan terhadap kepuasan dan loyalitas, dan hal tersebut secara implisit mencerminkan persepsi positif yang mengarah kepada minat untuk terlibat di dalam suatu keputusan (Wiradarma dan Suasana, 2019). Secara umum, persepsi anggota atas pelayanan koperasi dinilai sudah baik (Suherman dkk., 2013). Persepsi dan pelayanan kepada anggota telah dibuktikan signifikan secara parsial maupun simultan terhadap keberhasilan koperasi (Maemunah dkk., 2017). Kinerja lembaga sebagai perwujudan dari keberhasilan koperasi dapat ditentukan secara signifikan oleh kualitas pelayanannya (Sudarno dan Hasmuri, 2018). Kemudian, kualitas pelayanan dan manfaat koperasi juga dinyatakan berpengaruh positif terhadap partisipasi anggota pada koperasi (Mahri, 2006).

Hasil berbeda justru ditemukan peneliti lain, yang menyatakan bahwa minat berkoperasi dan partisipasi anggota koperasi walaupun berpengaruh signifikan terhadap kesejahteraan anggota, namun kualitas pelayanannya berpengaruh tidak signifikan terhadap kesejahteraan anggota (Catur dan Setiawina, 2018). Persepsi dinyatakan telah tidak berpengaruh nyata terhadap minat mahasiswa berkoperasi, sedangkan sikap dapat mendorong keikutsertaan anggota dalam berkoperasi (Anisah, dkk., 2016). Kondisi seperti ini, sangat potensi menyurutkan minat mahasiswa untuk berkoperasi. Data empiris menunjukkan bahwa parsipasi mahasiswa untuk menjadi anggota Kopma termasuk di Universitas Udayana masih tergolong sangat rendah. Koperasi Mahasiswa (Kopma) adalah wadah kegiatan kewirausahaan mahasiswa dan jumlah anggota Kopma sangat sedikit, sehingga perlu dilakukan sebuah penelitian untuk memahami minat mahasiswa untuk menjadi anggota Kopma (Putra, dkk., 2014). Sementara, pemerintah berharap bahwa pendidikan tinggi dapat berperan untuk mampu menumbuhkan minat mahasiswa agar memahami manfaat dan partisipasi berkoperasi melalui proses pembelajaran yang dikembangkan.

Kepala Dinas Koperasi dan UMKM Sulsel menegaskan untuk fokus menciptakan sumber daya manusia pengurus koperasi dari kalangan milenial. Program tersebut dijalankan di sejumlah kampus melalui Kopma yang berfungsi sebagai inkubator (https://sulselprov.go.id, 2019). Pemberian pemahaman koperasi ke generasi muda perlu dilakukan, selain untuk mendorong minat untuk berwirausaha atau berkoperasi, juga ditujukan untuk lebih mengenalkan koperasi kepada masyarakat secara luas. Sebagian besar masyarakat dipahami masih awam dalam menjalankan budaya koperasi. Kopma sebagai unit usaha yang melayani kebutuhan anggota atau mahasiswa, perannya menjadi sangat penting. Fungsi Kopma bagi mahasiswa sangat strategis, karena banyak kebutuhan mahasiswa yang seharusnya dapat dilayani. Namun, banyak mahasiswa yang tidak mengerti atau bahkan tidak peduli dengan keberadaan Kopma. Ketidak pedulain mahasiswa ini terjadi karena manfaat yang diperoleh mahasiswa tidak jelas, bahkan mahasiswa menjadi anggota pada koperasi yang relatif tidak besar, sehingga partisipasi mereka menjadi rendah (Kusumantoro, 2010). Mahasiswa sebagai generasi penerus bangsa seharusnya mampu menjadi pelopor untuk peduli dengan koperasi, sehingga dapat menjadi penggerak masyarakat agar peduli dan mau menjadi anggota koperasi (BEM-FEB. Unud, 2019). Semangat kewirausahaan para mahasiswa nampaknya belum dapat membentuk jati diri kewirausahaannya di civitas akademika (Wibowo dan Suasana, 2017). Di bagian lain, manajemen koperasi adalah salah satu mata kuliah wajib lulus bagi mahasiswa. 


\section{Gusti Agung Ketut Gede Suasana ${ }^{1}$, Anak Agung Gede Suarjaya ${ }^{2}$, I Made Dana ${ }^{3}$}

Akibatnya, masalah keanggotaan Kopma juga menjadi tantangan tersendiri bagi semua universitas. Berdasarkan uraian tersebut, maka penelitian ini menarik dilakukan untuk mendapatkan gambaran empiris terkait dengan rendahnya minat mahasiswa untuk berpartisipasi menjadi anggota Kopma.

\section{Landasan Teori dan Pengembangan Hipotesis}

\section{Pengaruh manfaat ekonomi dan non ekonomi terhadap minat berkoperasi}

Manfaat merupakan suatu nilai yang menunjukkan kapasitas potensial dari suatu objek atau aksi untuk memuaskan kebutuhan manusia yang dipandang dari sudut ekonomi dan nonekonomi (Hendar dan Kusnadi, 2005). Seseorang yang berminat menjadi anggota sebuah koperasi dapat dipastikan termotivasi oleh manfaat yang diharapkan berdasarkan atas kebutuhan tertentu yang dapat dipuaskan. Ketentuan dalam Permenkop dan UKM. RI. No. 9 Tahun 2018 pada bab IV, pasal 99 juga menyiratkan bahwa; (1) Usaha koperasi merupakan usaha yang berkaitan langsung dengan kepentingan anggota untuk meningkatkan usaha dan kesejahteraan anggota, (2) Kelebihan kemampuan pelayanan koperasi dapat digunakan untuk memenuhi kebutuhan masyarakat yang bukan anggota koperasi. Jadi, kebutuhan tersebut secara umum berupa kebutuhan yang bersifat ekonomi dan non-ekonomi (sosial). Minat seseorang untuk menjadi anggota koperasi, dapat dipastikan termotivasi dengan ekspektasi akan manfaat yang diperoleh. Produk Kopma adalah jasa layanan yang disesuaikan dengan kebutuhan, dan ditujukam untuk menarik minat menjadi anggota. Pada dasarnya, Kopma perlu melaksanakan strategi yang akurat untuk menarik, mendapatkan dan mempertahankan partisipasi anggota sebagai energi sektor koperasi di masa depan (Hasbullah, 2015). Beberapa aspek yang dapat dipergunakan untuk mengukur minat, yaitu; tertarik mencari informasi, mempertimbangkan untuk membeli, tertarik mencoba, ingin mengetahui, dan ingin memiliki (Schiffman dan Kanuk, 2007). Hasil penelitian menunjukkan terdapat pengaruh signifikan manfaat berkoperasi terhadap minat berkoperasi (Rukiati, 2016). Manfaat ekonomi berkoperasi bagi anggota sering diistilahkan dengan promosi ekonomi anggota, yaitu peningkatan pelayanan koperasi kepada anggota dalam bentuk manfaat ekonomi yang dapat diberikan (Irawan, 2015). Manfaat ekonomi dapat dgolongkan menjadi dua, yaitu manfaat ekonomi langsung (MEL) dan manfaat ekonomi tidak langsung (METL). Manfaat ekonomi langsung merujuk pada manfaat yang diterima anggota langsung pada saat terjadinya transaksi dengan koperasi. Sedangkan, manfaat ekonomi tidak langsung adalah manfaat yang diterima anggota sesaat setelah berakhirnya suatu periode tertentu atau periode pertanggungjawaban pengurus kepada anggota, yakni berupa pembagian sisa hasil usaha (SHU) anggota. Manfaat ekonomi tersebut biasanya bervariasi tergantung dari varian fitur layanan yang ditawarkan koperasi. Hasil penelitian menunjukkan bahwa koperasi memberikan manfaat ekonomi berupa manfaat ekonomi tunai dan diperhitungkan (Wiandhani dkk., 2016). Semakin besar manfaat ekonomi berkoperasi maka partisipasi anggota dalam memanfaatkan unit usaha koperasi akan semakin besar (Febrina, 2018). Motivasi berkoperasi ditemukan berpengaruh signifikan terhadap minat menjadi anggota koperasi (Pratama dan Widiyanto, 2019). Manfaat lebih sebagai anggota merupakan daya dorong yang kuat motivasi berkoperasi. Manfaat berkoperasi berpengaruh signifikan terhadap partisipasi anggota (Mahri, 2006). Peningkatan partisipasi anggota dapat mencerminkan minat keterlibatan seseorang atas kinerja yang ditawarkan koperasi. Manfaat ekonomi dan pemahaman terhadap koperasi juga memberikan efek positif terhadap minat mahasiswa menjadi anggota koperasi (Kusumantoro, 2010).

Koperasi juga dapat memberikan manfaat non-ekonomi atau manfaat sosial. Manfaat tersebut dapat mengilustrasikan perasaan kepuasan yang diharapkan oleh anggota koperasi. Kepuasan adalah perasaan senang atau kecewa seseorang yang muncul setelah membandingkan antara persepsi atau kesannya terhadap kinerja atau hasil suatu produk dan 


\section{Gusti Agung Ketut Gede Suasana ${ }^{1}$, Anak Agung Gede Suarjaya ${ }^{2}$, I Made Dana ${ }^{3}$}

jasa dengan harapannya (Kotler dan Keller, 2009:177). Kepuasan yang diterima oleh anggota koperasi pada dasarnya ditunjukkan oleh kinerja dan kualitas pelayanan yang diberikan koperasi. Kualitas pelayanan dapat diukur dari lima dimensi dan menurut kualitas jasa/pelayanan (service quality), yaitu; bukti langsung (tangibles), keandalan (reliability), ketanggapan atau daya tanggap (responsiveness), jaminan (assurance), dan empati (empathy) (Tjiptono, 2008:67). Manfaat non-ekonomi koperasi dapat ditunjukkan oleh perasaan seorang anggota terhadap kesesuaian pelayanan yang diterima dari kelima dimensi tersebut. Kualitas pelayanan koperasi dapat menciptakan partisipasi aktif anggota dalam pemerataan, pengorganisasian, dan pendayagunaan layanan usaha. Hasil penelitian menunjukkan bahwa terdapat hubungan positif antara kualitas layanan, kepuasan dan loyalitas anggota koperasi (Yacob et al., 2015; Nuryanti dan Kirwani,...). Kepuasan yang dirasakan anggota dalam menjadi anggota koperasi sudah sesuai dengan harapan (Wiandhani dkk., 2016). Pengaruh pelayanan terhadap keberhasilan koperasi ditemukan signifikan secara parsial maupun simultan (Maemunah dkk., 2017). Variabel pembelajaran manfaat koperasi mempengaruhi mahasiswa dalam berkoperasi (Anisah dkk., 2016). Kinerja koperasi, pada intinya akan memberikan manfaat ekonomi yang lebih besar daripada manfaat sosial (Fatmala dan Muflikh, 2017). Hasil uji hipotesis menggambarkan pengetahuan koperasi, kualitas pelayanan, dan motivasi berpengaruh signifikan terhadap minat menjadi anggota Kopma (Hidayah, dkk., 2017). Berdsarkan uraian tersebut diajukan hipotesis:

$\mathrm{H}_{1}$ : Manfaat ekonomi berpengaruh signifikan terhadap minat berkoperasi.

$\mathrm{H}_{2}$ : manfaat non ekonomi berpengaruh signifikan terhadap minat berkoperasi.

\section{Pengaruh manfaat koperasi terhadap persepsi mahasiswa.}

Persepsi anggota dalam berpartisipasi pada kontrol demokratis koperasi melebihi semua faktor lain di dalam menjelaskan keterlibatan anggota koperasi dan kepercayaannya terhadap pengurus (O'sterberg and Nilsson, 2009). Koperasi hanya sekedar usaha simpan pinjam, yang dilengkapi dengan berbagai berita negatif dan pengalaman pahit di masyarakat telah menjadi persepsi kebanyakan orang. Sehingga, koperasi menjadi stagnan, banyak yang tertinggal dari sentuhan teknologi dan automasi financial, serta managemen anggota yang tidak mudah (Sumahamijaya, 2018). Dimensi dan indikator pengukuran persepsi terhadap koperasi yang diaplikasikan peneliti sangat bervariasi. Pengukuran-pengukuran tersebut, adalah; perkembangan jumlah anggota, peran serta anggota, indeks pembayaran simpanan pokok, indeks pembayaran simpanan wajib, indeks transaksi usaha, perkembangan volume usaha, perkembangan SHU, perkembangan modal usaha, likuiditas, solvabilitas, profitabilitas, perkembangan pendapatan anggota, jumlah usaha, konsentrasi usaha (Anwar dkk., 2011); manfaat berkoperasi dan kesejahteraan anggota (Annisa dkk., 2011); dimensi manajemen dan pelayanan koperasi (Maemunah dkk., 2017); kinerja pengurus, kompetensi, dan kepuasan anggota (Rosmiati, 2018). Hasil penelitian menunjukkan terdapat pengaruh secara parsial dan simultan antara persepsi anggota dan pelayanan terhadap keberhasilan koperasi (Maemunah dkk., 2017). Persepsi anggota atas pelayanan karyawan koperasi juga dinilai sudah baik (Suherman, dkk., 2013). Indikator persepsi mahasiswa terhadap Kopma pada penelitian ini diukur melalui tiga dimensi, yaitu; pemahaman tentang Kopma, tujuan Kopma serta hak dan kewajiban anggota.

$\mathrm{H}_{3}$ : Manfaat ekonomi berpengaruh signifikan terhadap persepsi

$\mathrm{H}_{4}$ : Manfaat non-ekonomi berpengaruh signifikan terhadap persepsi

\section{Pengaruh persepsi terhadap minat berkoperasi}

Penelitian tentang minat telah banyak dilakukan dan umumnya dikaitkan dengan pembelian terhadap suatu produk (barang atau jasa), namun tidak banyak ditemui pada usaha koperasi. Minat adalah perilaku yang muncul sebagai respon terhadap objek yang 


\section{Gusti Agung Ketut Gede Suasana ${ }^{1}$, Anak Agung Gede Suarjaya ${ }^{2}$, I Made Dana ${ }^{3}$}

menunjukkan keinginan seseorang untuk melakukan suatu tindakan (Kotler dan Keller, 2009:15). Minat didasarkan atas evaluasi dan sikap seseorang terhadap barang/jasa dengan mempertimbangkan faktor eksternal, sehingga berdampak pada kesediaannya untuk megambil keputusan (Wen dan Li, 2013). Minat merupakan jenis keputusan yang ditujukan untuk mempelajari mengapa seseorang tertarik untuk melakukan sesuatu. Konstruksi seperti mengingat dan mengantisipasi, akan membantu minat seseorang dalam keputusan (Porter, at al., 1974). Jadi, minat adalah tahap kecenderungan seseorang untuk bertindak yang didasarkan atas persepsi pada harapam akan manfaatnya sebelum benar-benar melakukan suatu keputusan.

Persepsi merupakan proses di mana individu mengorganisasikan dan menafsirkan pola stimulus dalam lingkungan disekitar individu (Atkinson, 2000). Persepsi (perception) adalah sebuah proses yang dipergunakan seseorang untuk dapat mengerti, menyeleksi, mengorganisasi, dan menginterprentasikan informasi lingkungan (Diefendorff \& Richard, 2003; Kotler dan Amstrong, 2008:62). Upaya meningkatkan kemungkinan persepsi bukanlah hal baru sama sekali. Persepsi dapat dijadikan sebagai instrumen untuk melihat hal-hal yang biasanya tidak dapat diakses oleh visi organisasi atau untuk meningkatkan efisiensi dari kemampuan yang ada (Démuth, 2013). Persepsi pada penelitian ini terkait dengan sikap mahasiswa atas kinerja organisasi Kopma yang dapat dipercaya, melalui manfaat yang mampu disediakan untuk menarik minat partisipasi sebagai anggota. Kepercayaan berhubungan positif dengan komitmen afektif, komitmen kontinyu dan komitmen normatif angota (Hao, 2018). Sikap sangat penting dalam mempengaruhi niat loyal anggota koperasi, sehingga koperasi perlu menekankan pada strategi penting untuk menarik, mendapatkan dan mempertahankan partisipasi anggota (Hasbulah, 2015). Pada umumnya, rata-rata partisipasi anggota ditemukan sudah cukup tinggi, walaupun hal tersebut tidak memiliki hubungan yang signifikan dengan kinerja koperasi (Huang et al., 2015). Berdasarkan urian tersebut diajukan hipotesis ke lima:

$\mathrm{H}_{5}$ : Persepsi berpengaruh signifikan terhadap minat berkoperasi

\section{Peran persepsi sebagai pemediasi pengaruh antara manfaat koperasi dan minat berkoperasi.}

Undang-undang mengamanatkan bahwa koperasi tidak memiliki kewenangan untuk mewajibkan setiap orang untuk menjadi anggota koperasi. Pada dasarnya koperasi harus; tumbuh dari bawah (rakyat) bukan ditumbuhkan dari atas (pemerintah), organisasi independen, pengelolaan usahanya dengan prinsip swadaya, manajemen yang demokratis, anggota adalah pemilik sekaligus pelanggan koperasi, anggota harus mendapatkan kepuasan akan pelayanan tertentu, dan tugas utama koperasi adalah memuaskan kebutuhan anggotanya (Hendar, 2010). Dalam artian, setiap orang bebas menentukan dirinya untuk berpartisipasi di dalam koperasi ataukah tidak. Prinsip koperasi tersebut, secara positif dapat dimaknai bahwa badan usaha koperasi harus dapat tumbuh dan berkembang secara sehat, dewasa dan mandiri. Minat untuk menjadi anggota diharapkan dapat muncul atas dasar kebutuhan, manfaat yang diperoleh, dan kinerja yang ditawarkan koperasi. Manfaat berkoperasi dan kinerja pelayanan yang baik, secara umum akan menjadi stimulus minat dan komitmen seseorang untuk berkoperasi. Promotor koperasi, pemerintah, dan calon anggota harus memprioritaskan faktor-faktor yang berdampak lebih besar, yaitu komitmen anggota dan partisipasi pada kesuksesan daripada yang lainnya (Dejene, 2014). Komitmen afektif memiliki peran mediasi hubungan antara kepercayaan dan partisipasi dalam tata kelola koperasi, terlepas dari kepercayaan yang bersifat kognitif atau afektif (Didier et al., 2012). Ditemukan bahwa ekspektasi anggota berpengaruh positif terhadap persepsi dan kepuasan, persepsi mempengaruhi kepuasan dan sub-dimensinya secara positif, dan persepsi memiliki peran mediasi parsial pengaruh ekspektasi dan kepuasan (Akinci et al., 2018). Jadi, nilai yang dipersepsikan dapat memainkan peran sebagai perantara terpisah antara kualitas layanan dan konstruksi kepuasan (Hapsari et al., 2016). Oleh sebab itu, diajukan hipotesis enam dan tujuh: 
I Gusti Agung Ketut Gede Suasana ${ }^{1}$, Anak Agung Gede Suarjaya ${ }^{2}$ I Made Dana ${ }^{3}$

$\mathrm{H}_{6}$ : Persepsi berperan signifikan memediasi pengaruh antara manfaat ekonomi dan minat berkoperasi.

$\mathrm{H}_{7}$ : Persepsi berperan signifikan memediasi pengaruh antara manfaat non-ekonomi dan minat berkoperasi

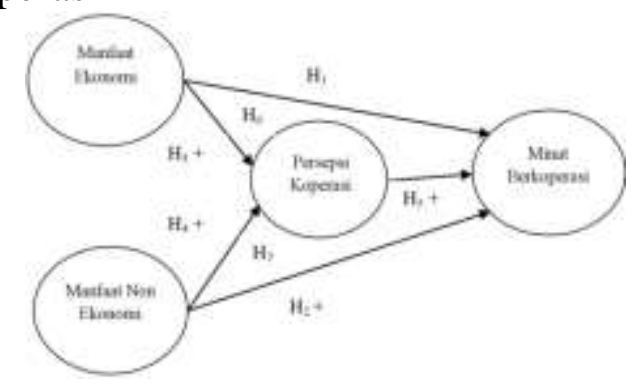

\section{Metode Penelitian}

Gambar 1: Kerangka Konsep Penelitian

Responden penelitian adalah semua mahasiswa $\mathrm{S}_{1}$ Fakultas Ekonomi dan Bisnis di Universitas Udayana (FEB-Unud) aktif, yang belum menjadi anggota Kopma Unud. Jumlah mahasiswa sampai pada periode Tahun 2019 adalah kurang lebih 890 orang. Penetapan ukuran sampel didasarkan pada jumlah indikator penelitian. Jumlah sampel yang dianggap representatif ditetapkan 5-10 dikalikan dengan jumlah indikator (Hair et.al., 2006:166). Jumlah indikator dalam penelitian sebanyak 35 unit, dengan demikian ukuran sampel dipergunakan adalah $5 \times 35=175$ responden, dan tersebar pada program $S_{1}$ untuk semua program studi. Analisis data dilakukan secara deskriptif dan multivariate. Analisis deskriptif ditujukan untuk menggambarkan kondisi demografis responden dan persepsi responden terhadap variablevariabel terukur. Analisis multivariate menggunakan model Analisis Jalur (Part Analysis) yang diawali dengan pengujian asumsi-asumsi dan prinsip-prinsip dasar analisis, meliputi; data berskala interval, uji normaliltas, linieritas, dan multikolinieritas.

\section{Hasil dan Pembahasan}

Rekapitulasi hasil análisis deskriptif seperti terlihat pada dapat dijelaskan sebagai berikut. Jenis kelamin responden, dominan (65,8 persen) adalah perempuan dan lama waktu kuliah diukur dari jumlah semester yang sudah dihabiskan, maka sebanyak 63,5 persen menyatakan sudah kuliah lebih dari empat semester dan sisanya 36,5 persen selama empat semester atau kurang. Ditemukan bahwa 45,3 persen responden dari prodi manajemen, 28,8 persen dari prodi ilmu ekonomi dan 25,9 persen dari prodi akuntansi. Responden tersebut dominan berasal dari wilayah lokal Bali yaitu sebanyak 85,9 persen dan sisanya 14,1 persen dari luar Bali. Tempat tinggal responden kabanyakan (80 persen) dengan orang tua/rumah sendiri dan hanya 20 persen yang mondok, sehingga wajar kalau ditemukan deskripsi responden kuliah penuh oleh 88,2 persen dan kuliah sambil kerja oleh 11,8 persen. Deskripsi menarik bahwa profesi orang tua responden ternyata kebanyakan 55,3 persen adalah pengusaha, 35,9 persen adalah karyawan dan hanya 8,8 persen dari kaluarga ASN. Secara logika genetika, kondisi pekerjaan orang tua seharusnya dapat dimanfaatkan sebagai kemudahan untuk menanamkan mind set minat untuk berkoperasi.

Analisis deskriptif minat berkoperasi diukur dengan 13 indikator dan secara umum diperoleh skor persepsi sebesar 3,69. Hasil ini berada pada rentang skala dengan kategori tinggi. Artinya bahwa, minat mahasiswa FEB-Unud untuk menjadi anggota Kopma dipersepsikan tinggi. Semua indikator pengukuran minat berkoperasi menunjukkan rata-rata skor pada kategori tinggi. Terdapat dua alasan terbaik yang menyebabkan minat mahasiswa tinggi, yaitu rasa bangga menjadi anggota kopma dan berbagai kemudahan yang diperoleh jika 


\section{Gusti Agung Ketut Gede Suasana', Anak Agung Gede Suarjaya ${ }^{2}$, I Made Dana ${ }^{3}$}

menjadi anggota Kopma. Kondisi ini menandakan bahwa Kopma Unud berpeluang besar jika memiliki program untuk memperkuat kelembagaan melalui peningkatan jumlah anggota.

Persepsi terhadap Kopma Unud diukur dengan enam indikator dan secara umum diperoleh skor persepsi sebesar 4,01. Hasil ini berada pada rentang skala dengan kategori kuat. Artinya bahwa persepsi mahasiswa FEB-Unud terhadap kinerja Kopma Unud dipersepsikan tinggi. Semua indikator pengukuran persepsi terhadap Kopma Unud menunjukkan rata-rata skor pada kategori kuat/tinggi. Terdapat dua alasan terbaik yang menyebabkan persepsi mahasiswa terhadap kinerja Kopma Unud adalah baik/kuat/tinggi, yaitu kopma dianggap sebagai wadah organisasi yang cocok bagi mahasiswa dan sekaligus dapat dijadikan ajang praktis untuk menambah pemahaman konsep bisnis khususnya tentang kewirakoperasian. Kondisi terendah profil Kopma Unud adalah pada informasi yang mudah didapatkan diberbagai media. Hal ini menandakan bahwa Kopma Unud harus berupaya memanfaatkan kombinasi berbagai media informasi yang akurat untuk sosialisasi program dan keberadaan organisasi. Sosialisasi ini sangat penting karena mahasiswa meyakini bahwa Kopma adalah lembaga yang sangat cocok sebagai wadah berorganisasi.

Manfaat ekonomi jika menjadi anggota Kopma Unud diukur dengan lima indikator dan secara umum diperoleh skor rata-rata persepsi sebesar 3,95. Hasil ini berada pada rentang skala dengan kategori baik. Artinya bahwa, mahasiswa FEB-Unud merasakan memperoleh manfaat ekonomi yang baik jika menjadi anggota. Semua indikator pengukuran terhadap manfaat ekonomi menjadi anggota Kopma Unud menunjukkan rata-rata skor pada kategori baik/kuat/tinggi. Terdapat tiga alasan penting yang perlu dicermati Kopma Unud yang menyebabkan persepsi mahasiswa terhadap manfaat berkoperasi di Kopma Unud adalah baik/kuat/tinggi. Alasan-alasan tersebut adalah; kondisi produk (barang/jasa) yang dijual adalah aman untuk dikonsumsi dan harga produk (barang/jasa) yang ditawarkan kepada anggota relatif lebih murah dibandingkan dengan harga di tempat lain, serta mendapatkan fasilitas lebih dalam hal kemudahan layanan kepada anggota.

Manfaat non ekonomi jika menjadi anggota Kopma Unud diukur dengan 11 indikator dan secara umum diperoleh skor rata-rata persepsi sebesar 3,95. Hasil ini berada pada rentang skala dengan kategori baik. Artinya bahwa, mahasiswa FEB-Unud merasakan memperoleh manfaat non ekonomi yang baik jika menjadi anggota. Semua indikator pengukuran terhadap manfaat non ekonomi menjadi anggota menunjukkan rata-rata skor pada kategori baik/kuat/tinggi. Terdapat empat alasan terpenting yang perlu dicermati Kopma Unud yang menyebabkan persepsi mahasiswa terhadap manfaat non ekonomi berkoperasi di Kopma Unud adalah baik/kuat/tinggi. Alasan-alasan tersebut adalah; karyawan Kopma Unud cukup sopan dalam pelayanan, prasarana atau fasilitas penunjang yang dimiliki untuk mendukung proses pelayanan di Kopma Unud adalah memadai, semua Staf Kompa Unud memberikan perhatian yang tulus pada setiap pelayanan kepada anggotanya, dan keramahtamahan pengurus Kopma Unud sesuai dengan harapan anggotanya.

Model persamaan I menunjukkan pengaruh variabel manfaat ekonomi dan non ekonomi terhadap persepsi mahasiswa pada Kopma, yaitu: $M=0,219 X_{1}+0,572 X_{2}$. Artinya, kedua variabel (manfaat ekonomi dan non ekonomi) tersebut secara parsial berpengaruh positif terhadap persepsi, dengan tingkat signifikansi kurang dari 0,05 $(<0,05)$. Pada model yang terbentuk, persepsi $(\mathrm{M})$ di pengaruhi oleh dua konstruk yaitu manfaat ekonomi $\left(\mathrm{X}_{1}\right)$ dan manfaat non ekonomi $\left(\mathrm{X}_{2}\right)$. Artinya, secara parsial ditemukan bahwa manfaat non ekonomi berpengaruh dominan yaitu sebesar 57,2 persen daripada manfaat ekonomi sebesar 21,9 persen. Besaran nilai $\mathrm{R}^{2}$ pada model I adalah sebesar 0,564 atau sebesar 56,4 persen. Artinya bahwa secara simultan sebesar 56,4 persen persepsi dijelaskan oleh manfaat ekonomi dan non ekonomi koperasi, dan sisanya 43,6 persen dijelaskan faktor lain yang tidak masuk di dalam model. Besaran $\mathrm{e}_{1}$ dapat ditentukan sebesar: $\mathrm{e}_{1}=\sqrt{ }(1-0,564)=0,6603$. 


\section{Gusti Agung Ketut Gede Suasana ${ }^{1}$, Anak Agung Gede Suarjaya ${ }^{2}$, I Made Dana ${ }^{3}$}

Model persamaan II menunjukkan pengaruh variabel manfaat ekonomi, non ekonomi dan persepsi mahasiswa pada Kopma terhadap minat berkoperasi, yaitu: $\mathrm{Y}=0,400 \mathrm{M}+0,157 \mathrm{X}_{1}$ $+0,277 \mathrm{X}_{2}$. Artinya, ketiga variabel bebas tersebut secara parsial berpengaruh positif terhadap minat berkoperasi, dengan tingkat signifikansi kurang dari 0,05 $(<0,05)$. Pada model tersebut terlihat bahwa minat berkoperasi dominan ditentukan oleh persepsi yaitu sebesar 40 persen, kemudian 27,7 persen oleh manfaat non ekonomi dan 15,7 persen oleh manfaat ekonomi. Besarnya nilai $\mathrm{R}^{2}$ model II adalah sebesar 0,571 atau sebesar 57,1 persen. Artinya bahwa secara simultan 57,1 persen minat berkoperasi mampu dijelaskan oleh manfaat ekonomi, manfaat non ekonomi, dan persepsi, sedangkan sisanya 42,9 persen dijelaskan oleh faktor lain yang tidak masuk di dalam model. Besaran $\mathrm{e}_{2}$ dapat ditentukan sebesar: $\mathrm{e}_{2}=\sqrt{ }(1-0,571)=0,6550$.

\section{Pengaruh manfaat ekonomi terhadap minat berkoperasi}

Hasil uji hipotesis telah membuktikan terdapat pengaruh positif dan signifikan manfaat ekonomi Kopma terhadap minat mahasiswa untuk menjadi anggota koperasi, dengan koefisien sebesar 15,7 persen. Artinya, atribut peningkatan manfaat ekonomi Kopma dapat menjadi daya tarik minat mahasiswa untuk menjadi anggota. Semakin banyak manfaat ekonomi yang dapat dinikmati, maka minat mahasiswa untuk menjadi anggota akan semakin tinggi. Manfaat ekonomi menjadi anggota Kopma, dibentuk dari; menikmati pembagian sisa hasil usaha, iuran anggota tidak memberatkan beban biaya hidup mahasiswa, harga barang/jasa relatif lebih murah dibandingkan dengan di tempat lain, barang/jasa yang dijual aman untuk dikonsumsi, dan anggota mendapatkan fasilitas kemudahan layanan. Berdasarkan hasil kajian deskripsi variabel dapat dijelaskan bahwa indek atas atribut manfaat ekonomi Kopma semuanya berada pada kategori tinggi, dengan skor total rata-rata dikategorikan tinggi. Hal tersebut dapat dimaknai bahwa semua responden sepakat bahwa manfaat ekonomi yang disajikan Kopma dinilai memuaskan.

Digambarkan lebih detail bahwa terdapat dua atribut dipersepsikan dengan skor tertinggi, yaitu selain harga/biaya di Kopma relatif lebih murah, dan transaksi atau konsumsi produk/jasa di Kompa juga aman. Hasil ini mencerminkan bahwa atribut-atribut tersebut, mampu memotivasi minat mahasiswa untuk menjadi anggota Kopma. Kondisi tersebut masuk akal, jika dilihat dari sisi deskripsi identitas. Profil mahasiswa dominan perempuan, asal Bali, tinggal di rumah sendiri, kuliah penuh, dan anak pengusaha. Jadi, kemungkinan mahasiswa berada di kampus seharian cukup tinggi, sehingga memerlukan tempat untuk makan dan keperluan lain terkait dengan kebutuhan kuliah sesuai dengan dayabeli. Hasil ini terdukung oleh hasil penelitian (Mahri, 2006) hasil penelitian menunjukan bahwa kualitas pelayanan dan manfaat koperasi berpengaruh positif terhadap partisipasi anggota koperasi. Annisa, dkk. (2018) menyatakan bahwa persepsi anggota tentang manfaat koperasi adalah positif, artinya manfaat koperasi dirasakan dan memberikan kontribusi positif kepada anggota dan mampu menjadi lembaga yang dapat mensejahterakan anggota.

\section{Pengaruh manfaat non ekonomi terhadap minat berkoperasi}

Uji hipotesis telah membuktikan terdapat pengaruh positif dan signifikan manfaat non ekonomi terhadap minat berkoperasi mahasiswa, dengan besaran koefisien sebesar 27,7 persen. Artinya, peningkatan manfaat non ekonomi bagi anggota Kopma akan meningkatkan minat mahasiswa untuk menjadi anggota. Semakin banyak manfaat non ekonomi yang dapat dinikmati, maka minat mahasiswa untuk menjadi anggota akan semakin tinggi. Manfaat non ekonomi menjadi anggota Kopma, dibentuk dari 11 atribut, yaitu; sarana layanan yang dimiliki lengkap, fasilitas penunjang tersedia memadai, penampilan karyawan, pelayanan karyawan yang cepat, pelayanan transaksi akurat, pelayanan kepada anggota sesuai harapan, kemampulayanan petugas cepat, pengelola cepat tanggap, karyawan yang sopan, perhatian tulus kepada anggota, dan keramahan pengurus. Berdasarkan hasil kajian deskripsi variabel 


\section{Gusti Agung Ketut Gede Suasana ${ }^{1}$, Anak Agung Gede Suarjaya ${ }^{2}$, I Made Dana ${ }^{3}$}

dapat dijelaskan bahwa indek atribut manfaat non ekonomi Kopma semuanya berada pada kategori baik/tinggi, dengan skor total rata-rata dikategorikan baik/lengkap. Makna dari hasil tersebut bahwa semua responden sepakat jika manfaat non ekonomi yang disediakan bagi anggota Kopma dinilai memuaskan. Digambarkan lebih detail bahwa terdapat tiga atribut dipersepsikan dengan skor tertinggi, yaitu; karyawan yang sopan, keramahan pengurus dan fasilitas penunjang tersedia memadai. Hasil ini mencerminkan bahwa atribut-atribut tersebut, dinilai mampu meningkatkan motivasi mahasiswa untuk berminat menjadi anggota Kopma. Profil mahasiswa jika dilihat dari hasil deskripsi identitas adalah dominan perempuan, asal Bali, tinggal di rumah sendiri, kuliah penuh, dan anak pengusaha. Jadi, kesopanan dan keramahan karyawan berserta pengurus dibutuhkan anggota Kopma sebagai bentuk perhatian serasa di rumahnya sendiri. Hasil ini terdukung dari hasil penelitian Zulfanedhi (2016) yang menenukan bahwa pengetahuan perkoperasian berpengaruh positif dan signifikan terhadap minat mahasiswa menjadi anggota kopma. Mahri (2006) menyatakan kualitas pelayanan dan manfaat Koperasi berpengaruh positif terhadap partisipasi anggota. Wiandhani, dkk. (2016), Manfaat non ekonomi berupa kepuasan yang dirasakan anggota dalam menjadi anggota koperasi, terhadap pelayanan dalam pemanfaatan unit usaha sudah sesuai harapan. Nuryanti dan Kirwani (2014) juga menyatakan kualitas layanan yang diberikan koperasi dinilai sesuai dengan harapan dan kebutuuhan anggota.

\section{Pengaruh manfaat ekonomi terhadap persepsi}

Pada hasil uji hipotesis telihat pengaruh positif dan signifikan manfaat ekonomi terhadap persepsi mahasiswa pada Kopma, dengan besaran koefisien sebesar 21,9 persen. Artinya, peningkatan manfaat ekonomi yang disediakan bagi anggota akan meningkatkan persepsi positif mahasiswa terhadap kinerja Kopma. Semakin banyak manfaat ekonomi yang dapat dinikmati anggota, maka persepsi atas kinerja Kopma akan semakin baik. Manfaat ekonomi menjadi anggota Kopma, dibentuk dari lima atribut, yaitu; menikmati pembagian sisa hasil usaha, iuran anggota tidak memberatkan beban biaya hidup mahasiswa, harga barang/jasa relatif lebih murah dibandingkan dengan di tempat lain, barang/jasa yang dijual aman untuk dikonsumsi, dan anggota mendapatkan fasilitas kemudahan layanan. Berdasarkan hasil kajian deskripsi variabel dapat dijelaskan bahwa indek atribut manfaat ekonomi Kopma semuanya berada pada kategori tinggi, dengan skor total rata-rata dikategorikan tinggi. Makna dari hasil tersebut bahwa semua responden sepakat jika manfaat ekonomi yang disediakan bagi anggota Kopma dinilai memuaskan. Digambarkan lebih detail bahwa terdapat dua atribut dinilai dengan skor tertinggi, yaitu selain harga/biaya di Kopma relatif lebih murah, dan transaksi atau konsumsi produk/jasa di Kompa juga aman. Hasil ini mencerminkan bahwa atribut-atribut tersebut, mampu membentuk persepsi positif mahasiswa terhadap kinerja Kopma. Jika dilihat dari profil mahasiswa pada deskripsi identitas, nampaknya mahasiswa membutuhkan kinerja organisasi yang dapat menggiring sikap positif terhadap Kopma. Hasil ini terdukung dari hasil penelitian Anisah, dkk. (2016) notivasi, persepsi dan pendapatan merupakan variabel yang tidak berpengaruh nyata terhadap mahasiswa berkoperasi, sedangkan sikap dapat mendorong keikutsertaan anggota dalam berkoperasi. Catur dan Setiawina, 2018) menemukan partisipasi anggota koperasi berpengaruh signifikan terhadap kesejahteraan anggota.

\section{Pengaruh manfaat non ekonomi terhadap persepsi}

Hasil uji hipotesis memperlihatkan pengaruh positif dan signifikan manfaat non ekonomi terhadap persepsi mahasiswa pada Kopma, dengan besaran koefisien sebesar 57,2 persen. Artinya, peningkatan manfaat non ekonomi yang disediakan bagi anggota akan meningkatkan persepsi positif mahasiswa terhadap kinerja Kopma. Semakin banyak manfaat non ekonomi yang dapat dinikmati anggota, maka persepsi terhadap kinerja Kopma akan semakin baik. Manfaat ekonomi menjadi anggota Kopma, dibentuk dari 11 atribut, yaitu; 


\section{Gusti Agung Ketut Gede Suasana', Anak Agung Gede Suarjaya ${ }^{2}$, I Made Dana ${ }^{3}$}

sarana layanan yang dimiliki lengkap, fasilitas penunjang tersedia memadai, penampilan karyawan, pelayanan karyawan yang cepat, pelayanan transaksi akurat, pelayanan kepada anggota sesuai harapan, kemampulayanan petugas cepat, pengelola cepat tanggap, karyawan yang sopan, perhatian tulus kepada anggota, dan keramahan pengurus. Analisis atas deskripsi variabel menunjukkan bahwa indek atribut manfaat non ekonomi Kopma semuanya berada pada kategori tinggi, dengan skor total rata-rata dikategorikan tinggi. Makna dari hasil tersebut bahwa semua responden sepakat jika manfaat non ekonomi yang disediakan bagi anggota Kopma dinilai memuaskan. Digambarkan lebih detail bahwa terdapat tiga atribut dinilai dengan skor tertinggi, karyawan yang sopan, keramahan pengurus dan fasilitas penunjang tersedia memadai. Hasil ini mencerminkan bahwa atribut-atribut tersebut, merupakan manfaat yang dinilai mampu meningkatkan persepsi positif mahasiswa terhadap kinerja Kopma. Profil mahasiswa jika dilihat dari hasil deskripsi identitas adalah dominan perempuan, asal Bali, tinggal di rumah sendiri, kuliah penuh, dan anak pengusaha. Jadi, kesopanan dan keramahan karyawan berserta pengurus dibutuhkan anggota Kopma sebagai bentuk perhatian serasa di rumahnya sendiri. Jika dilihat dari profil mahasiswa pada deskripsi identitas (Lampiran 5), nampaknya mahasiswa membutuhkan pelayanan yang dapat menggiring sikap positif terhadap Kopma. Hasil ini hampir mirip dengan hasil penelitian Suherman dkk. (2013) yang menemukan bahwa persepsi anggota atas pelayanan koperasi dinilai sudah baik. Maemunah dkk. (2017) menemukan pengaruh antara variabel persepsi anggota dan pelayanan koperasi terhadap keberhasilan koperasi, ditemukan signifikan secara parsial maupun simultan. Berbeda dengan Catur dan Setiawina (2018), Anisah, dkk. (2016) yang menemukan bahwa kualitas pelayanan koperasi berpengaruh tidak signifikan terhadap kesejahteraan dan persepsi anggota. Motivasi, persepsi dan pendapatan merupakan variabel yang tidak berpengaruh nyata terhadap mahasiswa berkoperasi, sedangkan sikap dapat mendorong keikutsertaan anggota dalam berkoperasi.

\section{Pengaruh persepsi mahasiswan terhadap minat berkoperasi}

Hasil uji hipotesis membuktikan bahwa terdapat pengaruh positif dan signifikan persepsi mahasiswa pada kinerja Kopma terhadap minat untuk menjadi anggota koperasi, dengan koefisien sebesar 40 persen. Artinya, persepsi positif mahasiswa pada kinerja Kopma, dapat mendorong minat mahasiswa untuk menjadi anggota. Semakin positif persepsi yang diberikan pada Kopma, maka minat mahasiswa untuk menjadi anggota akan semakin tinggi. Persepsi dibentuk dari enam indikator, yaitu; wadah berorganisasi yang cocok bagi mahasiswa, dikelola secara profesional, informasinya tentang Kopma mudah didapat, dapat dijadikan ajang praktis untuk menambah pemahaman konsep bisnis khususnya tentang kewirakoperasian, dan unit usaha atau kegiatan yang dikembangkan Kopma, sesuai dengan kebutuhan mahasiswa. Berdasarkan kajian deskripsi variabel dapat dijelaskan bahwa indek atas atribut persepsi mahasiswa pada Kopma semuanya berada pada kategori baik, dengan skor total rata-rata dikategorikan baik. Hal tersebut dapat dimaknai bahwa semua responden sepakat bahwa persepsi pada kinerja Kopma dinilai memuaskan. Digambarkan lebih detail bahwa terdapat dua atribut dipersepsikan dengan skor tertinggi, yaitu wadah berorganisasi yang cocok bagi mahasiswa, dam dapat dijadikan ajang praktis untuk menambah pemahaman konsep bisnis khususnya tentang kewirakoperasian. Hasil ini mencerminkan bahwa atribut-atribut tersebut, mampu memotivasi minat mahasiswa untuk menjadi anggota Kopma. Semakin cocok Kopma sebagai wadah organisasi dan semakin mampu Kopma memberikan tambahan pemahaman, maka minat mahasiswa untuk menjadi anggota Kopma akan semakin tinggi. Jadi, kinerja Kopma yang baik merupakan harapan anggota untuk menambah pemahaman praktis anggota yang belum didapatkan semasa kuliah terkait dengan teori-teori tentang perkoperasian. Hasil ini terdukung oleh hasil penelitian Zulfanedhi (2016) yang menemukan bahwa persepsi tentang koperasi berpengaruh positif dan signifikan terhadap minat mahasiswa menjadi anggota 


\section{Gusti Agung Ketut Gede Suasana ${ }^{1}$, Anak Agung Gede Suarjaya ${ }^{2}$, I Made Dana ${ }^{3}$}

kopma. Nurhuda (2018) juga menemukan terdapat hubungan antara persepsi tentang koperasi dengan minat berkoperasi. Maemunah dkk. (2017) yang menyatakan bahwa pengaruh variabel persepsi anggota terhadap keberhasilan koperasi signifikan secara parsial. Hampir mirip dengan Catur dan Setiawina (2018) yang menemukan bahwa minat berkoperasi dan partisipasi berpengaruh signifikan terhadap kesejahteraan anggota koperasi. Aspek manajemen koperasi secara signifikan mampu berpengaruh positif terhadap kualitas partisipasi anggota (Nurranto dan Saputro (2015). Jadi dapat disimpulkan bahwa terdapat hubungan yang positif antara kinerja pengurus dengan partisipasi anggota (Septiani, 2012). Hasil penelitian ini sedikit berlawanan dengan temuan Anisah, dkk. (2016) bahwa persepsi merupakan variabel yang tidak berpengaruh nyata terhadap mahasiswa berkoperasi.

\section{Persepsi sebagai pemediasi pengaruh manfaat ekonomi terhadap minat berkoperasi}

Hasil analisis menunjukkan bahwa hubungan antara manfaat ekonomi menjadi anggota Kopma dan persepsi mahasiswa pada Kopma adalah signifikan $\left(\mathrm{p}_{3}\right)$ dengan koefisiean, hubungan antara persepsi mahasiswa pada Kopma dan minat berkoperasi adalah signifikan $\left(\mathrm{p}_{5}\right)$, hubungan antara manfaat ekonomi menjadi anggota Kopma dan minat berkoperasi melalui persepsi juga signifikan dengan koefisien $(\beta)=0,088$. Hubungan antara manfaat ekonomi menjadi anggota Kopma dan minat berkoperasi tanpa melibatkan persepsi adalah signifikan dengan koefisien $\left(\beta^{\prime}\right)=0,157$. Nilai koefisien $(\beta)$ sebesar 0,088 lebih rendah dari nilai koefisien $(\beta$ ') yaitu sebesar 0,157 . Jadi hasil evaluasi tersebut menandakan bahwa variabel persepsi mahasiswa pada Kopma merupakan variabel mediasi sebagian (partial mediation) pengaruh manfaat ekonomi dengan minat mahasiswa untuk menjadi anggota Kopma dengan pengaruh total sebesar 0,245 (24,5, persen). Artinya, selain persepsi mahasiswa masih ada faktor lain yang memediasi hubungan manfaat ekonomi dengan minat mahasiswa untuk menjadi anggota Kopma. Hasil penelitian ini terdukung dengan penelitian yang dilakukan oleh Mahri (2006), Kusumantoro (2010), Wiandhani dkk. (2016), Febrina (2018) bahwa manfaat koperasi berpengaruh positif terhadap partisipasi anggota pada koperasi. Persepsi, manfaat ekonomi, dan pemahaman terhadap koperasi memberikan efek positif terhadap minat mahasiswa menjadi anggota koperasi. Koperasi memberikan manfaat ekonomi tunai dan semakin besar manfaat ekonomi koperasi maka partisipasi anggota dalam memanfaatkan unit usaha koperasi akan semakin besar. Hasil penelitian kurang terdukung dengan penelitian yang dilakukan Anisah, dkk. (2016), Catur dan Setiawina (2018) yang menemukan bahwa kualitas pelayanan koperasi dinyatakan tidak signifikan memengaruhi kesejahteraan anggota. Motivasi, persepsi dan pendapatan juga dinyatakan sebagai variabel yang tidak signifikan terhadap mahasiswa berkoperasi.

\section{Persepsi sebagai pemediasi pengaruh manfaat non ekonomi terhadap minat berkoperasi}

Hasil analisis menunjukkan hubungan antara manfaat non ekonomi menjadi anggota Kopma dan persepsi mahasiswa pada Kopma adalah signifikan $\left(\mathrm{P}_{4}\right)$, hubungan antara persepsi mahasiswa pada Kopma dan minat berkoperasi adalah signifikan $\left(\mathrm{P}_{5}\right)$, hubungan antara manfaat non ekonomi menjadi anggota Kopma dan minat berkoperasi melalui persepsi juga signifikan dengan koefisien $(\beta)=0,229$. Hubungan antara manfaat non ekonomi menjadi anggota Kopma dan minat berkoperasi tanpa melibatkan persepsi adalah signifikan dengan koefisien $\left(\beta^{\prime}\right)=0,277$. Nilai koefisien $(\beta)$ sebesar 0,229 lebih rendah dari nilai koefisien $\left(\beta^{\prime}\right)$ yaitu sebesar 0,277 . Jadi hasil evaluasi tersebut mengindikasikan bahwa variabel persepsi mahasiswa pada Kopma merupakan variabel mediasi sebagian (partial mediation) pengaruh manfaat non ekonomi terhadap minat menjadi anggota Kopma dengan pengaruh total sebesar 0,506 (50,6 persen). Artinya, selain persepsi mahasiswa masih ada faktor lain yang memediasi hubungan antara manfaat non ekonomi dan minat mahasiswa untuk menjadi anggota Kopma. Hasil penelitian ini terdukung dengan hasil penelitian; Mahri (2006), Suherman, dkk. (2013), 


\section{Gusti Agung Ketut Gede Suasana ${ }^{1}$, Anak Agung Gede Suarjaya ${ }^{2}$, I Made Dana ${ }^{3}$}

Wiandhani, dkk. (2016), Maemunah, dkk. (2017). Para peneliti tersebut menyatakan manfaat non-ekonomi berupa kepuasan yang dirasakan anggota dalam menjadi anggota koperasi sudah sesuai dengan harapan. Di mana pengaruh persepsi anggota dan pelayanan terhadap keberhasilan koperasi signifikan secara parsial maupun simultan. Kualitas pelayanan dan manfaat koperasi berpengaruh positif terhadap partisipasi anggota pada koperasi. Osterberg and Nilsson (2009) juga menekankan bahwa persepsi anggota tentang partisipasinya dalam fungsi kontrol justru melebihi faktor lain dalam menjelaskan keterlibatan dalam koperasi dan kepercayaannya pada pengurus. Hasil penelitian ini sedikit berbeda dari: Anisah, dkk. (2016), Catur dan Setiawina (2018) yang menemukan bahwa kualitas pelayanan koperasi tidak signifikan terhadap kesejahteraan anggota. Motivasi, persepsi dan pendapatan merupakan variabel yang tidak berpengaruh nyata terhadap minat mahasiswa berkoperasi.

\section{Kesimpulan}

Hasil analisis membuktikan terdapat pengaruh signifikan manfaat ekonomi Kopma terhadap minat mahasiswa untuk menjadi anggota koperasi. Di mana, peningkatan manfaat ekonomi yang disediakan Kopma dapat menjadi daya tarik minat mahasiswa untuk menjadi anggota. Artinya, semakin banyak manfaat ekonomi yang dapat dinikmati, maka minat mahasiswa untuk menjadi anggota akan semakin tinggi. Pengaruh antara manfaat non ekonomi Kopma dan minat berkoperasi mahasiswa adalah signifikan. Di mana, peningkatan manfaat non ekonomi bagi anggota Kopma akan meningkatkan minat mahasiswa untuk menjadi anggota. Artinya, semakin banyak manfaat non ekonomi yang dapat dinikmati, maka minat mahasiswa untuk menjadi anggota akan semakin tinggi. Pengaruh antara manfaat ekonomi dan persepsi mahasiswa pada Kopma adalah signifikan. Di mana, peningkatan manfaat ekonomi yang disediakan bagi anggota akan meningkatkan persepsi positif mahasiswa terhadap kinerja Kopma. Artinya, semakin banyak manfaat ekonomi yang dapat dinikmati anggota, maka persepsi atas kinerja Kopma akan semakin baik. Pengaruh manfaat non ekonomi terhadap persepsi mahasiswa pada Kopma adalah signifikan. Di mana, peningkatan manfaat non ekonomi yang disediakan bagi anggota akan meningkatkan persepsi positif mahasiswa terhadap kinerja Kopma. Artinya, semakin banyak manfaat non ekonomi yang dapat dinikmati anggota, maka persepsi terhadap kinerja Kopma akan semakin baik. Pengaruh antara persepsi mahasiswa pada Kopma dan minat untuk menjadi anggota koperasi adalah signifikan. Di mana, persepsi positif mahasiswa pada kinerja Kopma, dapat mendorong minat mahasiswa untuk menjadi anggota. Artinya, semakin positif persepsi yang diberikan pada Kopma, maka minat mahasiswa untuk menjadi anggota akan semakin tinggi. Persepsi mahasiswa pada Kopma secara signifikan mampu memediasi pengaruh manfaat ekonomi terhadap minat mahasiswa untuk menjadi anggota Kopma dan berperan sebagai variabel mediasi sebagian (partial mediation). Persepsi mahasiswa pada Kopma secara signifikan mampu memediasi pengaruh manfaat non ekonomi terhadap minat menjadi anggota Kopma dan berperan sebagai mediasi sebagian.

Kopma sebaiknya mengupayakan peningkatan manfaat ekonomi dan non ekonomi bagi anggotanya, sekaligus melakukan sosialisasi yang lebih gencar tidak terbatas hanya pada orientasi mahasiswa baru saja, tetapi juga memanfaatkan media informasi di universitas, media umum, sponsorship kegiatan mahasiswam, dan bila perlu sebagai gues lecturer mata kuliah koperasi di semua fakultas. Manajemen Kopma sebaiknya berjuang lebih keras dan profesional untuk meningkatkan kinerja organisasi dan usaha koperasi untuk dapat meningkatkan image tentang profil Kopma. Kopma sebaiknya dapat menyediakan unit-unit kegiatan bisnis yang sangat dibutuhkan mahasiswa, dengan memanfaatkan partnership sesuai dengan kebijakan pemerintah terhadap pengembangan koperasi. 


\section{Daftar Pustaka}

Alliah, N., Yanzi, H. dan Nurmalisa, Y. (2016). Persepsi Masyarakat terhadap Keberadaan Koperasi Mekar Sari dalam Meningkatkan Kesejahteraan Anggotanya. Jurnal Kultur Demokrasi, Vol. 5, N0, 2 (2016).

Amriadi, O.Z., Sumarno, dan Syabrusm H. (2017). Analisis Keberadaan Koperasi Mahasiswa (KOPMA) Universitas Riau. JOM. FKIP. Universitas Riau, Vol 4, No 1, 1-12

Anisah, F. \& Widyawati (2016). Analysis of Factors Affecting Student Agribusiness In cooperatives At the Faculty of Agriculture, University of Syiah Kuala. Jurnal Ilmiah Mahasiswa Pertanian Unsyah, Volume 1, Nomor 1, 550-559

Annisa, C.N., Parijo \& Aminuyati (2011). Persepsi Anggota Tentang Manfaat Koperasi Simpan Pinjam. Jurnal EPP. Vol. 8 No.1, 41-46

Anwar, K., Najib, M. \& Mursidah (2011). Persepsi dan Reaksi Masyarakat Terhadap Keberadaan KUD Serba Usaha. Jurnal EPP. Vol. 8 No.1, 41-46

Atkinson. (2000). Pengantar Psikologi. Edisi kesebelas, Jilid 2, Interaksara, Jakarta.

Badan Eksekutif Mahasiswa (BEM) FEB Unud. (2019). Kajian Koperasi: mundurnya koperasi Indonesia salah system atau salah organisasi? http://bemfeb-unud.com/2019/07/14/, diakses 24 Nopember 2019.

Catur, I.K. dan Setiawina, N.D. (2018). Faktor-Faktor yang Mempengaruhi Partisipasi Anggota Koperasi dan Kesejahteraan Anggota pada Koperasi Unit Desa (Kud) di Kabupaten Jembrana, E-Jurnal Ekonomi dan Bisnis Universitas Udayana, 7 (12), 2509-2534

Dejene, E. (2014). Assessment of Members Perceptions towards Factors Influencing the Success of Cooperatives (A survey of Agricultural Marketing Cooperatives in Becho Woreda). A Thesis Submitted in Partial Fulfillment of the Requirements for the Award of Master of Business Administration Degree (Marketing Specialization), Mekelle, Ethiopia

Démuth, A. (2013). Perception Theories. Edícia kognitívne štúdia, Project Innovative Forms of Education in Transforming University Education (code 26110230028), The text was prepared in the Centre of Cognitive Studies at the Department of Philosophy, Faculty of Philosophy in Trnava.

Didier, V.B., Henninger, M.C. \& Akremi. A.E. (2012). The Relationship Between Members' Trust and Participation in the Governance of Cooperatives: The Role of Organizational Commitment. International Food and Agribusiness Management Review, Volume 15, Issue $1,1-24$

Diefendorff, J. M., \& Richard, E. M. (2003). Antecedents and consequences of emotional display rule perceptions. Journal of Applied Psychology, 88(2), 284-294. https://doi.org/10.1037/0021-9010.88.2.284

Dinas Koperasi dan UMKM Sulsel. (2019). Diskop UMKM Sulsel Fokus Ciptakan SDM Kalangan Milenial, https://sulselprov.go.id., diakses Tanggal 4 Desember 2019

Dyer, W.W. (2010). The power of intention. Hay House, Inc.

Fatmala, E. \& Muflikh, Y.N. (2013). Analisis Hubungan Kinerja Partisipasi dan Manfaat Bagi Anggota Koperasi (Studi Kasus: Kud Puspa Mekar, Kabupaten Bandung Barat). In Forum Agribisnis: Agribusiness Forum, Vol. 3, No. 1, 17-32

Febrina, D. (2018). Manfaat Koperasi dan Tingkat Partisipasi Anggota Koperasi Simpan Pinjam (KSP) Subur Makmur Sejahtera, Kecamatan Seputih Banyak, Kabupaten Lampung Tengah. Skripsi, Fakultas Pertanian Universitas Lampung, Bandar Lampung

Hair, J.F., Black, W.C., Babin, B.J., Anderson, R.E. \& Tatham, R.L. (2006). Multivariate Data Analysis. Vol. 6, Pearson Prentice Hall, Upper Saddle River. 
Hao, J. (2018). Cooperative member commitment, trust and social pressure: the role of members' participation in the decision making. JEL Codes: M21, A12 (No. 2058-20185210).

Hapsari, R., Clemes, M.\& Dean, D. (2016). The Mediating Role of Perceived Value on the Relationship between Service Quality and Customer Satisfaction: Evidence from Indonesian Airline Passengers. Procedia Economics and Finance 35 (2016), 388-395

Hasbullah, N. (2015). Members' Attitude and Loyalty Intention in the Malaysian Consumer Co-Operatives. International Journal of Business and Social Science, Vol. 6, No. 12, 187-193

Hashim, H. bin M. \& Latiff, A.R. bin A. (2018). Perceptions of transformational leadership (TFL) style: A study on Malaysian cooperative board of directors. SHS Web of Conferences 56, 01004 (2018), https://doi.org/10.1051/shsconf/20185601004, 1-10

Hendar (2010). Manajemen Koperasi. Erlangga: Jakarta. Hal: 5-6

Hendar dan Kusnadi. (2005). Ekonomi Koperasi untuk Perguruan Tinggi. Lembaga, Jakarta

Irawan, D. (2015). Manfaat Berkoperasi. http://www. pibi-ikopin. om/index.Php/artikelbisnis/90-mamfaat-berkoperasi. Diakses Tanggal 5 Desember 2019.

Kemenkop \& UKM. (2017). Koperasi Menembus Generasi Milenial. Cooperatif, No. 07, September 2017

Kotler, P. \& Keller, K.L. (2009). Manajemen Pemasaran. Jilid I. Edisi ke 13, Erlangga, Jakarta.

Kotler, P. \& Armstrong, G. (2008). Prinsip-Prinsip Pemasaran. Edisi 12, Jilid 1 dan 2. Erlangga, Jakarta.

Kusumantoro (2010). Minat Mahasiswa Untuk Menjadi Anggota Koperasi Mahasiswa. Jurnal Jurnal Pendidikan Ekonomi Dinamika Pendidikan, Vol. V, No. 2, 147 - 155

Mahri, A.J.W. (2006). Pelayanan dan Manfaat Koperasi, Serta Pengaruhnya Terhadap Partisipasi Anggota (Suatu Kasus pada Koperasi Produsen Tahu Tempe Kabupaten Tasikmalaya). Media Komunikasi dan Informasi Pengabdian Kepada Masyarakat (abmas), Tahun 6, Nomor 6, Vol. 78.

Maemunah, M., Arpizal, H. \& Handayani, R. (2017). Pengaruh Persepsi Anggota Tentang Manajemen Koperasi dan Pelayanan Koperasi Terhadap eberhasilan KUD Sejahtera Sarana Jaya, http://repository.unja.ac.id/1811/1/A1A113038-ARTIKEL.pdf

Muhibbin, S. (2011). Psikologi Pendidikan dengan Pendekatan Baru, Bandung: Remaja Rosdakarya

Österberg, P \& Nilsson, J. (2009). Members' perception of their participation in the governance of cooperatives: the key to trust and commitment in agricultural cooperatives, Agribusiness an International Journal, Volume 25, Issue 2, 181-197, https://doi.org/10.1002/agr.20200.

Porter, L.W., Steers, R.M., Mowday, R.T., \& Boulian, P.V., 1974. Organizational commitment, job satisfaction, and turn over among psychiatric technicians. Journal of Applied Psychology, 1974, 59, 603-609.

Pratama, D., \& Widiyanto, W. (2019). Faktor yang Mempengaruhi Minat Mahasiswa Pendidikan Ekonomi Koperasi 2015 Menjadi Anggota Koperasi. Economic Education Analysis Journal, 7(3), 939-944. https://doi.org/10.15294/eeaj.v7i3.28323

Putra, A.W., Rukmi, H. S. \& Adianto, H. (2014). Peningkatan Minat Mahasiswa untuk Menjadi Anggota Koperasi Mahasiswa (KOPMA) Itenas Berdasarkan Teori Pembentukan Kelompok. Jurusan Teknik Industri, Jurnal Online Institut Teknologi Nasional (Itenas), No. 04, Vol. 02, Reka Integra

Rosmiati (2018). Hubungan Persepsi Anggota tentang Kinerja dan Kompetensi Pengurus dengan Kepuasan Anggota Koperasi pada KUD Sumber Makmur Kecamatan Sungai 
I Gusti Agung Ketut Gede Suasana ${ }^{1}$, Anak Agung Gede Suarjaya ${ }^{2}$ I Made Dana ${ }^{3}$

Bahar Kabupaten Muaro Jambi. Journal of Economic and Management Scienties, Vol.1 No. $1,40-46$

Rukiati (2016). Persepsi Manfaat Koperasi Terhadap Minat Berkoperasi Masyarakat Kelurahan Pangkabinanga Kecamatan Pallangga Kabupaten Gowa. Diploma thesis, UPT. Perpustakaan, Universitas Negeri Makassar.

Schiffman, L.G., Kanuk, L.L.(2007). Perilaku Konsumen. Alih Bahasa: Zoelkifli Kasip. Jakarta: Indeks

Sudarno dan Hasmuri, 2018. Pengaruh Kualitas Pelayanan (Service Quality), Penghargaan (Reward) dan Kepuasan Wajib Pajak Kendaraan Bermotor Terhadap Capaian Kinerja Lembaga - Studi Empiris di Unit Pelaksana Teknis Pendapatan Badan Pendapatan Daerah Provinsi Riau. INOBIS: Jurnal Inovasi Bisnis dan Manajemen Indonesia, Volume 1, Nomor 2, 196-213

Suherman, Bambang G.S, dan Syahrudin, H. (2013). Persepsi Anggota Terhadap Kualitas Pelayanan pada Koperasi Syariah Bmt Miftahus Salam Desa Wajok Hulu, Artikel Penelitian, Program Studi Pendidikan Ekonomi FKIP Untan

Sumahamijaya, I. (2018). Memajukan Perekonomian Indonesia dengan Revolusi Koperasi. Artikel, Indonesia Development Forum: Inspire, Imagine, Innovate-Initiate.

Tjiptono, F. (2008). Service Management Mewujudkan Layanan Prima. Yogyakarta: Andi Offset

Thoharudin \& Suriyanti, (2017). Peranan Koperasi Mahasiswa dalam Membentuk Mental Enterpreneurship Mahasiswa. Sosio Didaktika: Social Science Education Journal, 4 (2), 74-86

Walgito, B. (2010). Pengantar Psikolog Umum. Yogyakarta: C.V Andi Offset

Wen, L.Y.M. and Li, S.H. (2013). Consciouness, Ecological Affect, and Purchase Intetion of Green Production. Journal of Organizational Innovation, 5 (4), 124-137.

Wiandhani, N., Lestari, D.A.H. \& Soelaiman, A. 2016. Analisis Manfaat Ekonomi dan Non Ekonomi Koperasi Perikanan ISM Mitra Karya Bahari. JIIA, Volume 4 No. 1, Januari 2016

Wibowo, A.C. \& IGAKG. Suasana (2017). Pengaruh Efikasi Diri, Pengambilan Risiko, dan Inovasi Terhadap Niat Berwirausaha Mahasiswa FEB. Universitas Udayana. E-Jurnal Manajemen Unud, Vol. 6, No. 10, 2017: 5693-5719

Wiradarma, IGM. \& Suasana, IGAKG. (2019). Peran Kepuasan Pelanggan Memediasi Pengaruh Kualitas Pelayanan terhadap Loyalitas Pelanggan Pull\&Bear Kuta-Bali. EJurnal Manajemen Unud, Vol. 8, No. 6, 3987-4016

Yacob, Y., Ali, J.K. Baptist, C.J., Nadzir, H.M. \& Morshidi, H.M. (2015). How Far Members' Satisfaction Mediated Members' Loyalty, Investigating Credit Cooperative in Sarawak Borneo. 6th International Research Symposium in Service Management, IRSSM-6 2015, 11-15 August 2015, UiTM Sarawak, Kuching, Malaysia, 376-383

Zeuli, K.A. and Cropp, R. (2004). Cooperatives: Principles and practices in the 21st century. the fourth and most extensive revision of the Marvin A. Schaars' text, Cooperatives, Principles and Practices, University of Wisconsin Extension-Madison, Publication A1457, July 1980.

Undang-Undang Dasar Negara Republik Indonesia 1945.

Undang-undang Republik Indonesia, No. 25, Tahun 1992, tentang perkoperasian

Permenkop dan UKM. RI. No. 9 Tahun 2018. Tentang Penyelenggaraan dan Pembinaan Perkoperasian 